\title{
Pyric-Herbivory to Promote Rangeland Heterogeneity: Evidence From Small Mammal Communities
}

\author{
Samuel D. Fublendorf, ${ }^{1}$ Darrell E. Townsend II, ${ }^{2}$ R. Dwayne Elmore, ${ }^{3}$ and David M. Engle ${ }^{4}$
}

Authors are ${ }^{1}$ Sarkey's Distinguished Professor, ${ }^{2}$ Research Assistant, ${ }^{3}$ Assistant Professor, and ${ }^{4}$ Professor and Director of Water Research and Extension Center, Department of Natural Resource Ecology and Management, Oklahoma State University, Stillwater, OK 74078, USA.

\begin{abstract}
Management of rangelands has largely operated under the paradigm of minimizing spatially discrete disturbances, often under the objective of reducing inherent heterogeneity within managed ecosystems. This has led to a simplified understanding of rangelands and in many cases simplified rangelands. We argue that this type of management focus is incapable of maintaining biodiversity. An evolutionary model of disturbance (pyric-herbivory) suggests that grazing and fire interact through a series of feedbacks to cause a shifting mosaic of vegetation patterns across the landscape and has potential to serve as a model for management of grasslands with an evolutionary history of grazing. Our study demonstrates that the spatially controlled interaction of fire and grazing can be used to create heterogeneity in grassland ecosystems and the resulting heterogeneity in vegetation is expressed through other trophic levels, specifically small mammals in this study. Discrete fires were applied to patches, and patchy grazing by herbivores promoted a shifting vegetation mosaic across the landscape that created unique habitat structures for various small mammal species. Peromyscus maniculatus was about 10 times more abundant on recently burned patches (1-2 mo) than the uniform treatment or unburned patches within the shifting mosaic treatment. Chaetodipus hispidus was about 10 times greater in patches that were 15-20 mo post-fire in the shifting mosaic treatment than in the uniform treatment. Sigmodon hispidus, Microtus ochrogaster, and Reithrodontomys fluvescens became dominant in the shifting mosaic in patches that were more than $2 \mathrm{yr}$ post-fire. This study, along with others, suggests that by managing transient focal patches, heterogeneity has the potential to be a new central paradigm for conservation of rangeland ecosystems and can enhance biological diversity and maintain livestock production across broad scales.
\end{abstract}

\section{Resumen}

El manejo de los pastizales en gran medida ha operado bajo el paradigma de minimizar los disturbios espacialmente discretos, con el objetivo de reducir la heterogeneidad inherente dentro de los ecosistemas manejados. Esto ha llegado a una comprensión simplificada en el entendimiento de los pastizales y en muchos casos simplifica los pastizales. Debatimos que este tipo de manejo sería incapaz de mantener la biodiversidad. Un modelo evolutivo de disturbio (fuego-pastoreo) sugiere que el pastoreo y el fuego interactúan a través de una serie de reacciones para causar un mosaico cambiante de patrones de vegetación a través del paisaje y tienen un potencial para servir como modelo para el manejo de los pastizales con la historia evolutiva del pastoreo. Nuestro estudio demuestra que las interacciones espacialmente controladas del fuego y el pastoreo pueden utilizarse para crear la heterogeneidad en los ecosistemas de pastizales y la heterogeneidad resultante en la vegetación se expresa a través de otros niveles tróficos, específicamente de pequeños mamíferos en este estudio. Se aplicaron quemas aisladas a espacios y pastoreos irregulares por medio de herbívoros para promover un mosaico de la vegetación cambiante a través del paisaje que crearon estructuras únicas del hábitat para varias especies de mamíferos pequeños. Peromyscus maniculatus fue aproximadamente 10 veces más abundante en las áreas quemadas recientemente (1-2 meses) que en el tratamiento uniforme o en la áreas sin quemar en el mosaico cambiante. Chaetodipus hispidus fue alrededor de 10 veces mayor en espacios que tenían de 15-20 meses de quemados en el tratamiento del el mosaico cambiante que en el tratamiento uniforme. Sigmodon hispidus, Microtus ochrogaster and Reithrodontomys fluvescens fueron los dominantes en el mosaico cambiante en los parches que tenía más de 2 años de quemados. Este estudio junto con otros sugiere que manejando áreas focales transitorias, la heterogeneidad tiene el potencial para ser un nuevo paradigma central para la conservación de los ecosistemas de tierras de pastoreo y puede aumentar la diversidad biológica y mantener la producción de ganado a través de una amplia escala.

Key Words: biodiversity, fire, grazing, landscape ecology, patch dynamics, wildlife

\section{INTRODUCTION}

This research was funded by the Oklahoma Agricultural Experiment Station, The Nature Conservancy, and the National Research Initiative of the US Department of Agriculture Cooperative State Research, Education and Extension Service, grant numbers 2003-3510112928 and 2006-35320-17476.

Correspondence: Samuel D. Fuhlendorf, Oklahoma State University, 008C Ag Hall, Stillwater, OK 74078, USA. Email: sam.fuhlendor@okstate.edu

Manuscript received 19 March 2010; manuscript accepted 16 July 2010.
Heterogeneity has many definitions, but relevant parameters in the context of grassland ecosystems are the variability in the biotic and abiotic components of an ecosystem, which influence ecosystems' structure and function (Kolasa and Pickett 1991; Ludwig and Tongway 1995; Wiens 1997). Heterogeneity is the root of biological diversity at all levels of ecological organization and should serve as the foundation for conservation and ecosystem management (Christensen 1997; Ostfeld et al. 1997; 
Fox and Fox 2000). Understanding the variability inherent within ecosystems or associated with variable patterns of disturbance is critical in describing and managing the structure and function of ecosystems. However, most approaches to managing grassland ecosystems are based on an equilibrium paradigm that rarely considers spatial or temporal variability (Fuhlendorf and Engle 2001; Briske et al. 2003). Thus, it is not surprising that many species that evolved under this dynamic disturbance pattern are in decline.

Grasslands are inherently heterogeneous, in that composition, productivity, and diversity are highly variable across multiple scales (Ludwig and Tongway 1995; Patten and Ellis 1995; Fuhlendorf and Smeins 1999). Heterogeneity can result from differential timing of disturbances and corresponding out of phase succession among patches; spatial heterogeneity of resources associated with topoedaphic patterns; or competitive interactions among plant species (Fuhlendorf and Smeins 1998). It is well accepted that grasslands evolved with disturbance, including fire and grazing. However, until recently the spatial patterns of these disturbances were not recognized. Recent descriptions have indicated that disturbance patterns on the Great Plains led to a shifting mosaic where at any point in time the landscape included areas that had recently been burned and/or grazed as well as areas that had not been disturbed for several years or decades (Fuhlendorf et al. 2009). The ecological interaction of fire and grazing, termed pyricherbivory (literally interpreted as grazing that is driven by fire), is different than a statistical interaction because it drives a series of feedbacks that results in a landscape pattern. The attraction of grazing animals to recently burned areas and avoidance of unburned areas suggests that from an evolutionary perspective fire and grazing were coupled disturbance processes. Many of the wildlife species that are declining on grasslands today evolved on prairies that are best described as heterogeneous across many spatio-temporal scales, largely due to this pyric herbivory (Fuhlendorf et al. 2009). Also, heterogeneity may be just as critical to many abiotic patterns and ecosystem processes, such as water and nutrient cycling (Ludwig and Tongway 1995; Anderson et al. 2006). Therefore, it is critical that we develop conservation approaches that embrace heterogeneity on grassland ecosystems rather than attempt to remove heterogeneity, a common goal of rangeland managers.

A key component of heterogeneity, and thus biological diversity, is the frequency and intensity of disturbances such as fire and grazing (Collins 1992; Fuhlendorf and Smeins 1999). However, most research decouples the effects of these disturbances by focusing on the main effects of grazing or fire, with little or no attention given to their interaction in space and time. Our contrasting model argues that grazing and fire interact as a coupled disturbance through a series of positive and negative feedbacks causing a shifting mosaic of vegetation patterns across the landscape (Hobbs et al. 1991; Fuhlendorf and Engle 2001). According to this coupled disturbance model, the probability of fire is greatest on areas with high biomass accumulation within a grazed grassland landscape. A positive feedback occurs when a recent fire event in an area of accumulated biomass subsequently attracts grazing animals, which further disturbs the site. As an example of this, bison (Bos bison L.) preferentially graze the most recently burned patches from a diverse landscape that includes patches with variable fire histories (Coppedge and Shaw 1998; Fuhlendorf et al. 2009). The model predicts that tall graminoid species decrease in dominance, and bare ground and forbs increase on recently burned patches that are focally grazed in response to fire patterns. These changes in composition and productivity are associated with a negative feedback because focal grazing reduces biomass, which reduces the probability of fire. The grazing animal subsequently focuses on other patches that have been burned more recently (Coppedge et al. 1998a, 1998b), allowing tall graminoids to recover dominance. The landscape includes local patches that have been burned and heavily grazed dispersed within a patchwork of patches in various states of structure and composition (Fuhlendorf and Engle 2001). Cattle likewise have been shown to follow the same pattern as bison (Fuhlendorf and Engle 2001; Fuhlendorf and Engle 2004; Fuhlendorf et al. 2006).

This shifting vegetation mosaic likely influences population dynamics and movement patterns of fauna native to Great Plains grasslands that have been described as fire dependent (Wiens 1976; Forman and Godron 1986). We expect that because these grassland landscapes evolved under pyric herbivory (Hobbs et al. 1991; Fuhlendorf and Engle 2001), our shifting mosaic model will produce alternative habitat types that could enhance biodiversity if applied at the appropriate scales. Because small mammals are sensitive indicators of habitat structure and typically the most numerous group of mammal taxa throughout the native prairie ecosystems of the Great Plains (Grant and Birney 1979; Rose and Birney 1985; Fox and Fox 2000; Fox et al. 2003), they serve as an excellent model to study the response of wildlife to the shifting mosaic model where fire and grazing are coupled as a single disturbance. Thus, our overall goal is to study two contrasting management strategies (pyric herbivory, referred to as the Shifting Mosaic treatment, and a Uniform Grazed treatment where grazing and fire are applied homogenously) for their ability to provide a variety of habitats for small mammals. Both of these treatments include the interaction of fire and grazing so that one is relatively heterogeneous and one is relatively homogeneous. We hypothesized that species composition of small mammal communities would vary within the habitats that are part of the shifting mosaic (heterogeneous). We further hypothesized this mosaic landscape would have a greater variety of small mammal communities than management units that are managed traditionally to promote homogeneity, and the variability in the mosaic would be largely driven by time since fire.

\section{MATERIAL AND METHODS}

\section{Study Site}

The study area is located about $21 \mathrm{~km}$ southwest of Stillwater, Oklahoma (lat 36 $3^{\prime} 53^{\prime \prime}$; long $97^{\circ} 13^{\prime} 52^{\prime \prime}$ ), and managed by Oklahoma State University. The climate is continental with an average frost-free growing period of $204 \mathrm{~d}$ extending from April to October. Average annual precipitation for the area is $83 \mathrm{~cm}$ with $65 \%$ falling as rain from May to October. The mean annual temperature is $15^{\circ} \mathrm{C}$ with an average daily minimum of $-4.3^{\circ} \mathrm{C}$ in January to an average daily maximum of $34^{\circ} \mathrm{C}$ in August. Major soil and community types (ecological sites) on the study area were shallow prairie, loamy prairie, 
eroded prairie, and sandy savanna. Most of this area would be classified as typical of tallgrass prairie, but some local communities are representative of cross timbers vegetation (post oak [Quercus stellata Wang.] and eastern redcedar [Juniperus virginiana L.]). Dominant grasses included little bluestem (Schizachyrium scoparium [Michx.] Nash), big bluestem (Andropogon gerardii Vitman), and indiangrass (Sorghastrum nutans [L.] Nash). The dominant forbs were western ragweed (Ambrosia cumanensis Kunth) and the exotic sericea lespedeza (Lespedeza cuneata [Dum.-Cours.] G. Don). All units have been burned historically to minimize the encroachment of eastern redcedar.

\section{Experimental Design}

We used a completely randomized design to evaluate the firegrazing model. We evaluated two treatments that consisted of 1) spring and summer burning of spatially distinct patches within a treatment unit and free access by moderately stocked cattle (Shifting Mosaic treatment), and 2) no burning during this study (but burned on a 3-yr interval) with free access by moderately stocked cattle (Uniform Grazed treatment). Each treatment was between 45 ha and 65 ha and was replicated three times (a total of six pastures). Experimental units (i.e., pastures) of both treatments were treated similarly and had the same stocking rate except for the application of spatially discrete fires in the Shifting Mosaic treatment. Soils and topography were similar for all pastures. In both the Uniform Grazed and Shifting Mosaic treatments, the experimental unit consisted of a pasture divided into six distinct patches. Fences surrounded each experimental unit, i.e., each of six fenced pastures, but free movement of animals was allowed within each. In the Shifting Mosaic treatment, one-sixth of the experimental unit was burned each spring (March to April) and one-sixth each summer (July to October). Contiguous patches within each Shifting Mosaic treatment pasture were burned sequentially to assure a 3-yr return interval. No patches were burned in the Uniform Grazed treatment during the study, but the entire pasture was burned once every 3 yr. Summer and spring fires were included in treatments but both were under prescriptions that were based on objectives of removal of herbaceous biomass rather than woody plant control. Thus the fires had relatively low intensities (Twidwell et al. 2009).

\section{Vegetation Sampling}

We collected pretreatment data of vegetation for all pastures in 1999. Vegetation composition was again sampled late August to early September during 2001 and 2002 to evaluate treatment response. For each patch within each treatment, we recorded canopy cover of plant functional groups and selected species of interest (Sericea lespedeza, forbs, S. scoparium, tallgrass, annual grasses, other grasses, and total grass) and of bare ground and leaf litter by cover classes within $30 \quad 0.1-\mathrm{m}^{2}$ randomly located quadrats (Fuhlendorf and Engle 2004). As an index of heterogeneity in a previous study, we calculated the mean standard deviation of quadrat samples among patches within each treatment, and a comprehensive analysis indicated that the Shifting Mosaic treatment was over three times more heterogeneous than the Uniform Grazed treatment (Fuhlendorf and Engle 2004).
Table 1. Total number of captures across all sampling sessions for the seven species captured and analyzed in this study. Detrended Correspondence Analysis (DCA) Axis 1 and Axis 2 species scores are given for each species, indicating their position on the DCA analysis.

\begin{tabular}{lccc}
\hline \multicolumn{1}{c}{ Species } & $\begin{array}{c}\text { No. of } \\
\text { captures }\end{array}$ & $\begin{array}{c}\text { DCA axis 1 } \\
\text { species score }\end{array}$ & $\begin{array}{c}\text { DCA axis 2 } \\
\text { species score }\end{array}$ \\
\hline Chaetodipus hispidus & 38 & 216 & 288 \\
Peromyscus maniculatus & 538 & 262 & 27 \\
Microtus ochrogaster & 289 & 0 & 84 \\
Reithrodontomys fluvescens & 227 & 86 & 103 \\
Sigmodon hispidus & 283 & 111 & 178 \\
Peromyscus leucopus & 6 & 170 & -49 \\
Reithrodontomys montanus & 8 & 126 & -75 \\
\hline
\end{tabular}

\section{Small Mammal Sampling}

Species of small mammals detected in our study were Sigmodon hispidus, Reithrodontomys fluvescens, Microtus ochrogaster, Chaetodipus hispidus, Peromyscus maniculatus, P. leucopus, and R. montanus. They were censused on each patch of each treatment once during May through June, August through September, November through December of 2001 and March through April, July through August, and October through November of 2002. Each sampling period consisted of $18 \mathrm{~d}$. To prevent any bias associated with changes in weather patterns (i.e., temperature or rainfall) likely to influence trap success, we randomly paired patches so that a portion of each treatment was sampled concurrently. We randomly placed two $40 \times 40 \mathrm{~m}$ grids in tallgrass prairie habitat within each patch. Trapping grids had 10-m spacing between traps so that each grid contained 25 traps. One trapping occasion was restricted to one patch pair per replication (i.e., 100 traps per patch pair per replication, or 300 traps). Each sampling period required six trapping occasions (i.e., six patch pairs per replication) where each trapping occasion was sampled for three consecutive nights (i.e., one sampling period required 18 trap nights).

Mammals were trapped with Sherman live-traps $(7.6 \times 8.9 \times 22.9 \mathrm{~cm})$ baited with rolled oats and supplied with cotton for bedding during fall and winter trap sessions. Upon capture each animal was identified to species (Table 1), sex and age (adult or juvenile) were determined, and each individual was marked. Rodent trapping conformed to guidelines sanctioned by the American Society of Mammalogists. Relative abundance was computed as the number of individual animals caught per 100 trap nights. A trap night was defined as one functional trap open for one 24-h period (McMurry et al. 1996). Traps found sprung and empty were not included in data analyses.

\section{Statistical Analysis}

Statistical analyses focus on small mammals with vegetation data used as explanatory variables because comprehensive analysis of vegetation has been thoroughly presented in previous publications (Fuhlendorf and Engle 2004). We used multivariate and univariate analyses to describe the relationship of small mammals to fire-grazing treatments and vegetation variables. Detrended Correspondence Analysis (DCA) was used on small mammal data to determine general 
Table 2. Average (SE) cover of plant functional and habitat measurements in Shifting Mosaic and Uniform Grazed treatments during 2001 and 2002 at the Oklahoma State University Stillwater Research Range. Shifting Mosaic treatments are divided into months since fire to represent the variability of vegetation among patches. A comprehensive analysis of the plant community has been previously published (Fuhlendorf and Engle 2004).

\begin{tabular}{|c|c|c|c|c|}
\hline & \multirow{2}{*}{$\begin{array}{l}\text { Uniform } \\
\text { grazed }\end{array}$} & \multicolumn{3}{|c|}{ Shifting mosaic-months since fire } \\
\hline & & $<12$ & $12-24$ & $>24$ \\
\hline Tallgrasses & $27.4(4.9)$ & $7.3(2.6)$ & $15.2(3.3)$ & $21.5(2.6)$ \\
\hline Little bluestem & $18.3(4.1)$ & $10.2(1.0)$ & $16.5(2.4)$ & $23.9(4.8)$ \\
\hline Other perennial grasses & $20.9(2.2)$ & $20.8(1.3)$ & $27.2(3.2)$ & $27.8(2.4)$ \\
\hline Annual grasses & $1.7(0.5)$ & $1.0(0.4)$ & $1.5(0.6)$ & $1.2(0.4)$ \\
\hline Forbs & $16.6(2.5)$ & $31.0(6.5)$ & $26.2(3.4)$ & $19.5(2.4)$ \\
\hline Sericea lespedeza & $9.6(3.0)$ & $2.5(1.0)$ & $4.4(1.6)$ & $4.6(2.7)$ \\
\hline Bare ground & $1.5(0.8)$ & $36.9(4.1)$ & $17.4(4.8)$ & $5.3(2.1)$ \\
\hline Litter & $58.2(5.4)$ & $21.2(4.1)$ & $36.4(5.2)$ & $52.6(3.8)$ \\
\hline
\end{tabular}

patterns of variability and identify relationships with time since fire (Fuhlendorf and Smeins 1997; Fuhlendorf et al. 2002). Pearson correlation coefficients were used to determine directional trends between small mammal species and time since fire in shifting mosaic treatments. For correlations, we pooled similar times since fires across years so points would not overlap. Correlation analysis was used to identify relationships between small mammals and vegetation characteristics. Significance was determined for $P$ values at $\alpha=0.10$. All lines presented in figures were significant at the same level. Our objectives were not focused on modeling the specific habitat dynamics of each species but rather on identifying simple relationships of small mammal communities and species with the fire-grazing treatments.

\section{RESULTS}

\section{Vegetation Composition and Structure}

Previous comprehensive analyses of vegetation patterns during this study have been published (Fuhlendorf and Engle 2004), so we focus most of our evaluation of the vegetation on identifying relationships among treatments and small mammal communities. Vegetation composition and structure of patches within the Uniform Grazed treatment were similar among patches and dominated by tallgrasses, little bluestem, and other perennial grasses (Table 2). Overall, there was a dominance of grasses, high cover of litter, minimal bare ground, and no significant differences among patches within the Uniform Grazed treatment, indicating that the landscape was homogenous. In contrast, bare ground, litter, and cover of plant functional groups were highly variable among patches within the Shifting Mosaic treatment (Table 2). Patches with recent $(<12 \mathrm{mo})$ focal disturbance of fire and grazing had almost twice the forb cover and almost 20 times more bare ground than the Uniform Grazed treatment. As time since fire and grazing (focal disturbance) increased, grasses (tallgrasses, little bluestem, and other perennial grasses) and litter increased and forbs and bare ground decreased. So, because of the intense focal disturbances of fire and grazing followed by several years

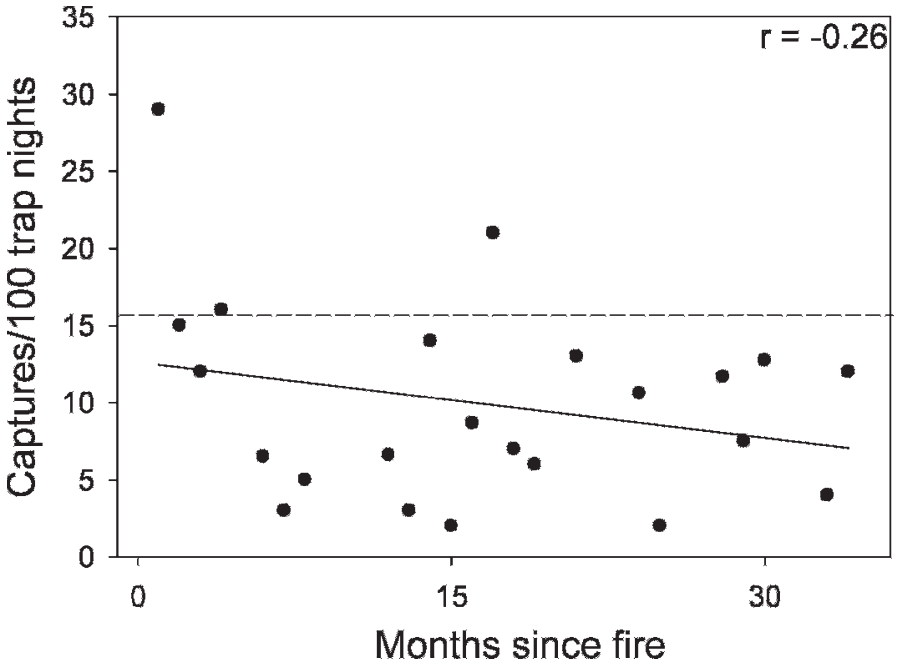

Figure 1. Capture rate (captures per 100 trap nights) of small mammals in the Shifting Mosaic and Uniform Grazed treatments in tallgrass prairie. A correlation between time since fire and small mammal capture rate is presented for the Shifting Mosaic treatment. The dashed line illustrates the overall pooled capture rate for the Uniform Grazed treatment during the same time.

of reduced grazing pressure within the Shifting Mosaic treatment, habitat heterogeneity had increased over that of Uniform Grazed management, resulting in variable habitats driven by time since fire (and associated grazing) within the Shifting Mosaic treatment (for comprehensive evaluation of vegetation heterogeneity see Fuhlendorf and Engle 2004).

\section{Small Mammal Community}

Species richness and capture number of small mammals varied by treatment and time since fire in the Shifting Mosaic treatment. Twice as many $P$. maniculatus were captured as any other species. M. ochrogaster, S. hispidus, and $R$. fluvescens represented the next most abundant species captured (Table 1). Trend in total capture rate in the Shifting Mosaic treatment indicated a slight negative trend (Fig. 1). Species richness increased up to 30 mo since fire in the Shifting Mosaic treatment to a level comparable to that of the Uniform Grazed treatment (Fig. 2). Species richness was greatest in patches that had been burned about 30 mo before sampling in the Shifting Mosaic treatment. Recently burned patches produced the most captures (i.e., highest abundance), but these patches were species poor and dominated generally by one or two species. Both treatments contained the same number of total species and the same species, but the recently disturbed patches included unique communities in terms of dominance.

Small mammal community composition varied both with treatment and with time since fire within the Shifting Mosaic treatment. The first two axes of the DCA analysis had eigenvalues of 0.54 and 0.25 , respectively. Separation of samples along the first two ordination axes reflects treatment differences (Fig. 3a). Species scores for Axis 1 indicate that $C$. hispidus (216) and P. maniculatus (262) were dominant in some patches of the Shifting Mosaic treatment, while $M$. ochrogaster (0) and $R$. fluvescens (86) were more dominant in the Uniform Grazed treatment (Table 1). Species with high 


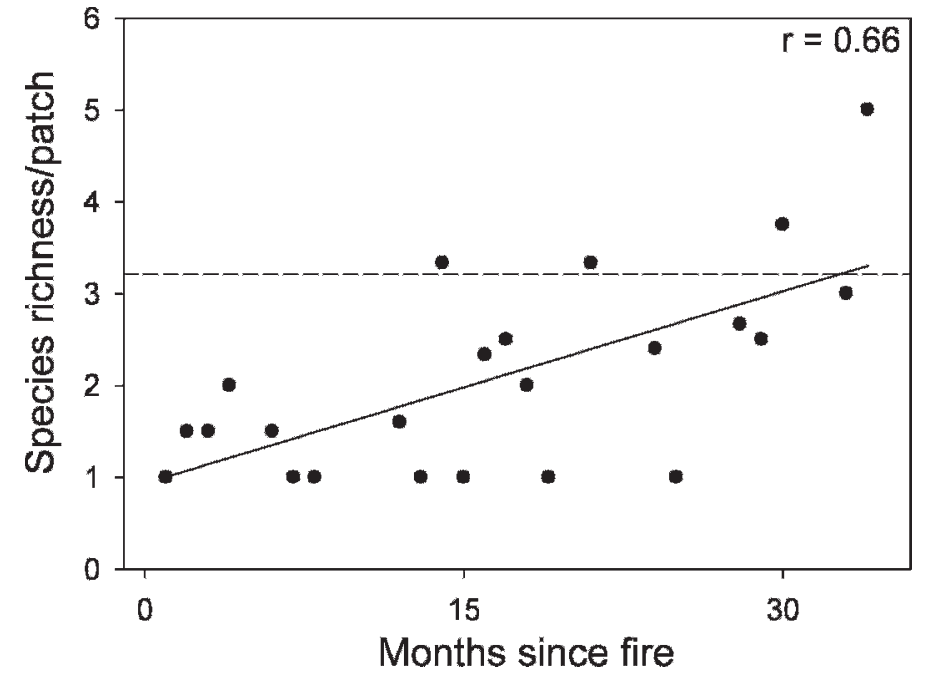

Figure 2. Species richness of small mammals in the Shifting Mosaic and Uniform Grazed treatments are presented for tallgrass prairies in Oklahoma. A correlation between months since fire and species richness is presented for the Shifting Mosaic treatment. The dashed line illustrates the overall pooled species richness for the Uniform Grazed treatment during the same time.

DCA Axis 1 scores were most abundant on Shifting Mosaic treatments, while low scores indicate greater abundance in the Uniform Grazed treatment. Variation in DCA Axis 1 and 2 among patches within the Shifting Mosaic treatment were correlated with time since fire (Figs. $3 \mathrm{~b}$ and $3 \mathrm{c}$ ), indicating that the dominant variation among sampled communities is due largely to time since fire.

Correlation coefficients support the multivariate analyses, indicating that some small mammals were more abundant in recently burned and grazed patches (negative correlation with time since fire) and some were more abundant in relatively undisturbed patches (positive correlation). These results support our hypothesis of dependency of species composition on the shifting mosaic model (Figs. 4 and 5). The most abundant species was $P$. maniculatus, found primarily in the Shifting Mosaic treatment where it was most abundant on most recently burned patches (Fig. 4). This species was largely responsible for the high capture rate on recently burned and grazed areas, and its dominance only occurred in the Shifting Mosaic treatment. C. hispidus was also found mostly in the Shifting Mosaic treatment and was most abundant at the intermediate time since focal disturbance, although the correlation with time since fire was not significant (Fig. 4). Alternatively, captures of M. ochrogaster, R. fluvescens, and S. hispidus increased with time since focal disturbance, and all but the latter were most abundant in the Uniform Grazed treatment.

\section{Relationships Between Vegetation and Small Mammals}

Small mammals were sensitive to varied vegetation structure created in the Shifting Mosaic treatment. C. hispidus and $P$. maniculatus were positively correlated with bare ground and forbs and negatively correlated with litter (Table 3). P. maniculatus also were negatively correlated with cover of tallgrasses (Table 3). This supports the capture data that indicate these two species prefer patches that have been
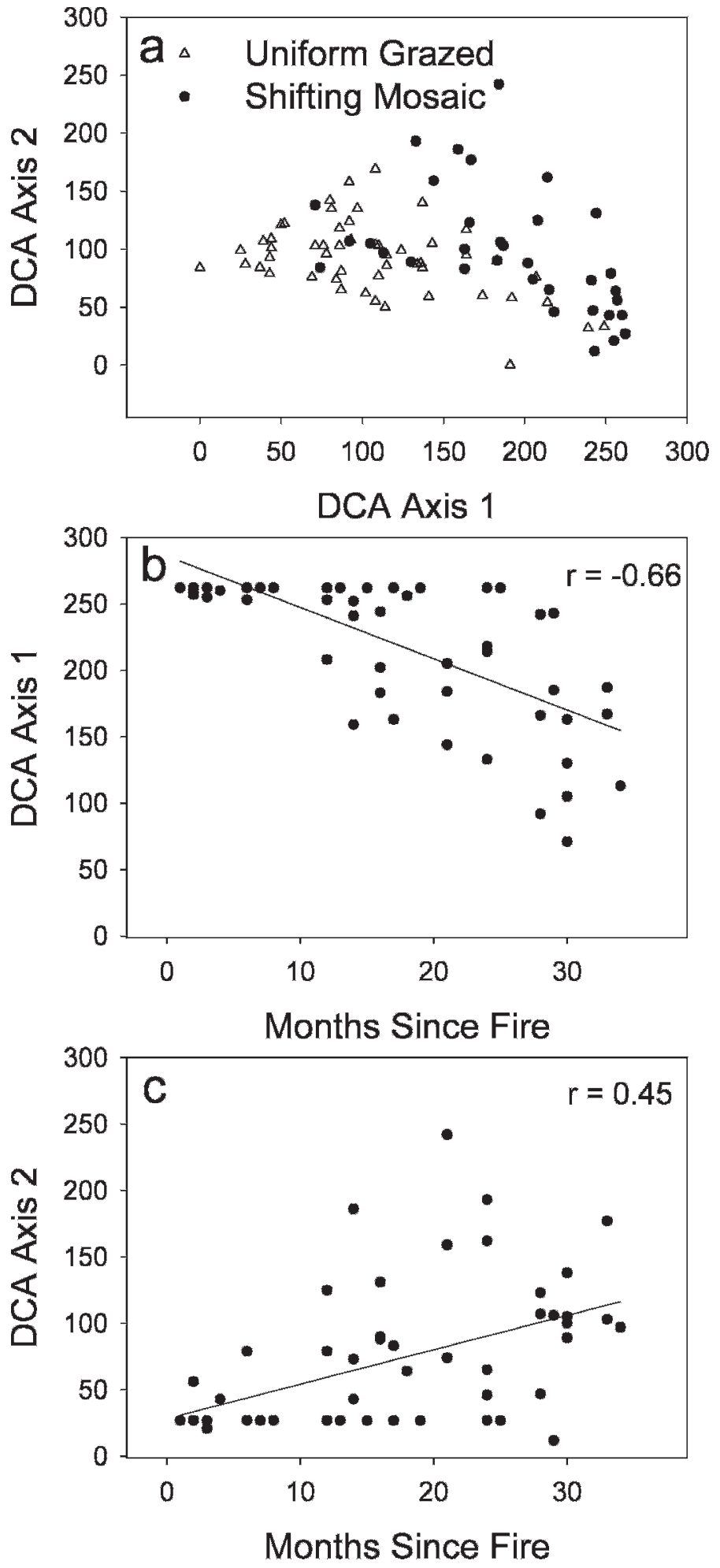

Figure 3. Plots of the first two axes of the Detrended Correspondence Analysis (DCA) for a, Axis 1 and Axis 2 sample scores for all patches from both treatments, $\mathbf{b}$, the correlation between time since fire and DCA Axis 1 of the Shifting Mosaic treatment only, and c, the correlation between time since fire and DCA Axis 2 of the Shifting mosaic treatment only.

disturbed recently by fire and intense grazing. M. ochrogaster, $R$. fluvescens, and S. hispidus were positively correlated with litter and negatively correlated with bare ground (Table 3). $M$. ochrogaster and R. fluvescens were also negatively correlated 

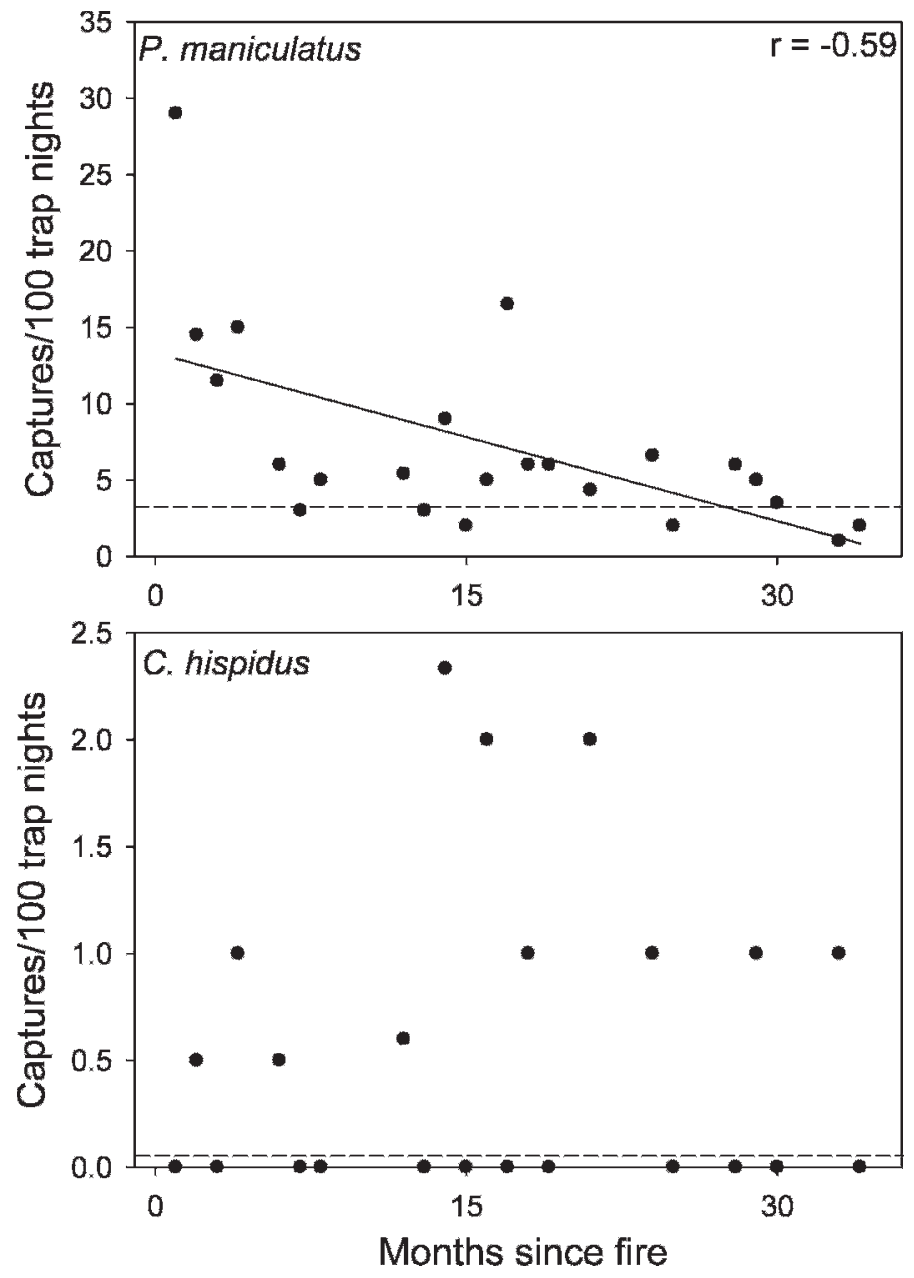

Figure 4. Total capture rates per 100 trap nights are presented for $P$. maniculatus and $C$. hispidus in the Shifting Mosaic and Uniform Grazed treatments from tallgrass prairie. The relationship of months since fire and each species capture rates are demonstrated for the Shifting Mosaic treatment. C. hispidus was more abundant in the Shifting Mosaic treatment, but the relationship with time since fire was not significant. The dashed line illustrates the overall pooled capture rate for the Uniform Grazed treatment during the same time.

with cover of forbs. M. ochrogaster was correlated positively with tallgrass and total grass cover (Table 3). M. ochrogaster, R. fluvescens, and S. hispidus were most abundant in habitats that are characterized by homogenous habitat structure resulting from uniform moderate disturbance.

\section{DISCUSSION}

Many ecologists appreciate the role of variability in ecosystem structure and function, but few conservation practices have been developed that embrace spatial and temporal variability. In fact, for grassland ecosystems, most management and research has focused on reducing both spatial and temporal variability often to the demise of biodiversity (Fuhlendorf and Engle 2001). For example, rotational grazing is often implemented to promote uniform utilization of pastures by grazing animals (Bailey et al. 1996; Teague et al. 2004). Previous analyses have demonstrated that uniform distribution does not
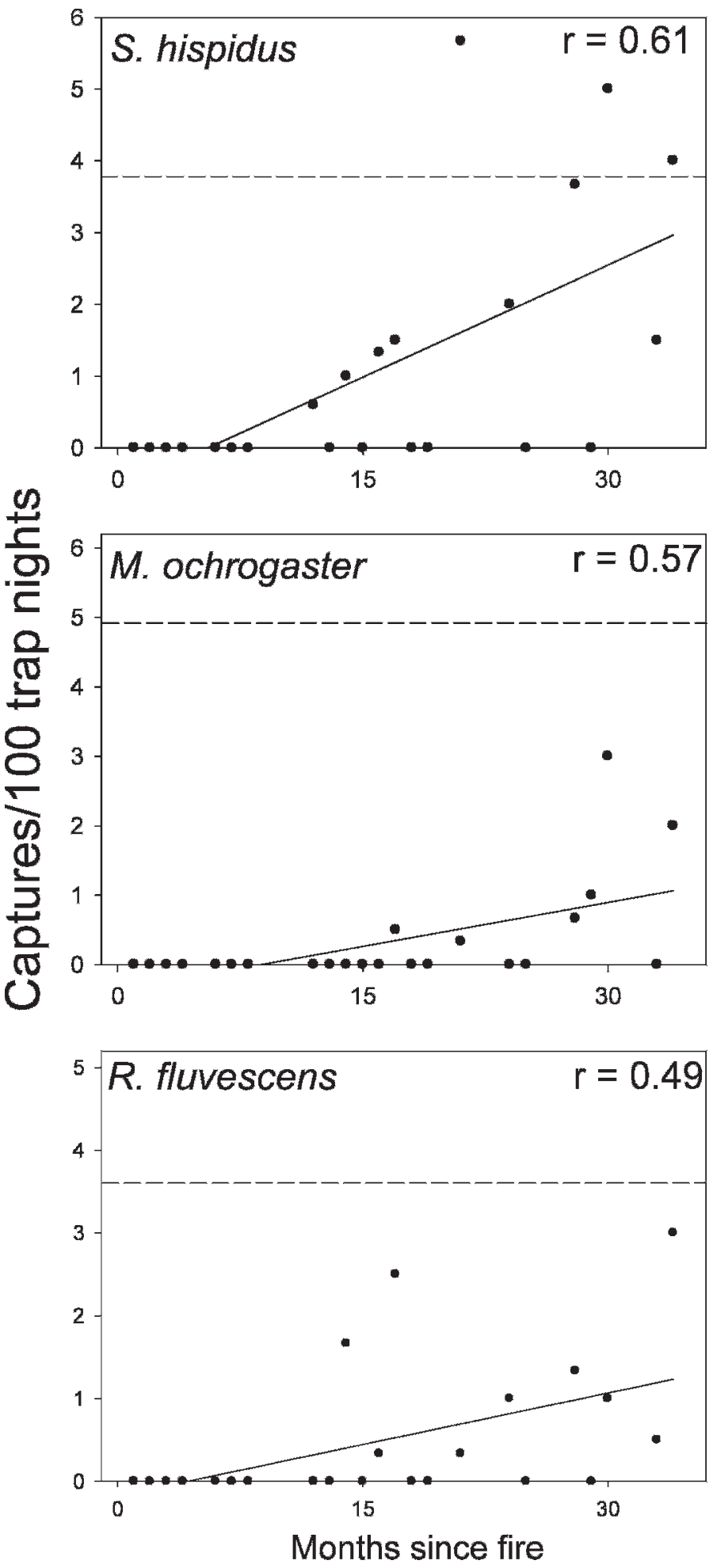

Figure 5. Total capture rates per 100 trap nights are presented for $S$. hispidus, M. ochrogaster, and R. fluvescens in the Shifting Mosaic and Uniform Grazed treatments from tallgrass prairie in Oklahoma. The correlations of months since fire and each species capture rates are demonstrated for the Shifting Mosaic treatment. The dashed line illustrates the overall pooled capture rate for the Uniform Grazed treatment during the same time. 
Table 3. Correlation coefficients for the relationships between vegetation cover and small mammal abundance on the Oklahoma State University Range Research Station, Stillwater, Oklahoma, 2002.

\begin{tabular}{|c|c|c|c|c|c|c|c|c|c|c|}
\hline \multirow[b]{2}{*}{ Vegetation cover type } & \multicolumn{2}{|c|}{ C. hispidus } & \multicolumn{2}{|c|}{ P. maniculatus } & \multicolumn{2}{|c|}{ M. ochrogaster } & \multicolumn{2}{|c|}{ R. fluvescens } & \multicolumn{2}{|c|}{ S. hispidus } \\
\hline & $r$ & $P$ & $r$ & $P$ & $r$ & $P$ & $r$ & $P$ & $r$ & $P$ \\
\hline Bare ground & 0.38 & 0.024 & 0.31 & 0.070 & -0.55 & $<0.001$ & -0.49 & 0.003 & -0.44 & 0.008 \\
\hline Leaf litter & -0.43 & 0.009 & -0.39 & 0.018 & 0.65 & $<0.001$ & 0.51 & 0.001 & 0.40 & 0.016 \\
\hline Forb & 0.52 & 0.001 & 0.35 & 0.037 & -0.52 & 0.001 & -0.52 & 0.001 & -0.25 & 0.136 \\
\hline S. scoparium & -0.15 & 0.392 & 0.17 & 0.315 & -0.07 & 0.704 & 0.16 & 0.342 & -0.06 & 0.726 \\
\hline Tallgrass & -0.09 & 0.596 & -0.34 & 0.044 & 0.57 & $<0.001$ & 0.13 & 0.467 & 0.23 & 0.172 \\
\hline Total grass & -0.05 & 0.770 & -0.18 & 0.283 & 0.30 & 0.074 & 0.06 & 0.714 & 0.12 & 0.485 \\
\hline
\end{tabular}

increase livestock production and in some cases can simplify rangelands and result in a need for more supplemental feeding (Fuhlendorf and Engle 2004; Briske et al. 2008).

This focus has led to a paradigm of grassland conservation based on intermediate disturbance, where the objective is to reduce the area that is heavily disturbed and reduce the area that is undisturbed by maximizing uniform intermediate disturbance. This type of management is referred to as homogenization or "management toward the middle," is incapable of maintaining diversity of grassland ecosystems, and is the result of a simplified understanding of grassland disturbance (Fuhlendorf et al. 2006). A grassland conservation paradigm is needed that is based on heterogeneity and complex interactions among processes that contribute to a full range of disturbance patterns. Our study demonstrates that pyric herbivory (the spatially controlled interaction of fire and grazing) can be used to create heterogeneity in grassland ecosystems (Fuhlendorf and Engle 2004), and the resulting heterogeneity in vegetation is expressed through other trophic levels, specifically small mammals.

\section{Uniform Grazed Treatment}

In our study, the Uniform Grazed management (with the associated moderate stocking rates and uniform distribution of livestock) promoted minimal variation in vegetation structure. It maintained high densities of small mammals but compositional dominance was restricted to species that prefer dense biomass and high cover of litter characterized by uniform moderate to light grazing pressure and no fire. M. ochrogaster and $R$. fluvescens numerically dominated these sites, reflecting habitat preferences for these species (Kaufman and Fleharty 1974; Clark et al. 1998). C. hispidus were rare and P. maniculatus were a minor component in the Uniform Grazed treatment because these management units lacked intensively disturbed areas (Fuhlendorf and Engle 2004).

Periodic fire is required to maintain grasslands and minimize encroachment of woody plants that eventually impoverish grassland flora and fauna (Bragg and Hulbert 1976; Collins et al. 1995; Fuhlendorf et al. 1997; Coppedge et al. 2001; Briggs et al. 2002). However, periodic fires under Uniform Grazed treatment would typically be uniformly applied across the entire management unit. This could provide habitat for the species that require greater disturbance (C. hispidus and $P$. maniculatus), which are currently limited in the Uniform Grazed treatment, but it would in turn minimize habitat available for species that require dense vegetation structure and cover of litter (M. ochrogaster and R. fluvescens). Overall, the result would be greater instability in the small mammal communities because of lack of refugia for species with habitat requirements that are not included in the uniform treatment, particularly if applied at large scales.

\section{Shifting Mosaic Grasslands}

Alternatively, the Shifting mosaic treatment restored heterogeneity to the vegetation (structure and composition) that resulted in distinct small mammal communities associated with time since fire and grazing similar to previous analyses of bird communities (Fuhlendorf et al. 2006). C. hispidus and $P$. maniculatus were dominant only on recently burned patches that experienced focal grazing, while $M$. ochrogaster, $R$. fluvescens, and S. hispidus increased with time since fire. Maintenance of diversity thus required reducing dominant species. In other words, the Shifting Mosaic treatment decreased the relative abundance of some species but increased the occurrence of species that were rare under the Uniform Grazing system. Coupling fire-grazing as an interaction of the two disturbances decreased the overall abundance of $M$. ochrogaster and $R$. fluvescens, but the species were still dominant within some patches. Variability in the small mammal community among patches in the Shifting Mosaic treatment suggests that if biodiversity is truly the goal, the conservation of grassland ecosystems should focus on maintaining heterogeneity, and the fire-grazing interaction is a powerful tool for this approach.

Focal fire and subsequent grazing by large herbivores act in concert to reduce tallgrasses and increases herbaceous dicots over traditional management approaches (Fuhlendorf and Engle 2004). These habitat types, which persist for approximately 1-2 yr in tallgrass systems, are characterized by high levels of bare ground and highly variable vertical structure supporting species such as $P$. maniculatus and C. hispidus (Kaufman et al. 1983; Kaufman et al. 1988; Clark et al. 1998). Tallgrasses regain dominance and litter cover increases after $2 \mathrm{yr}$. These predictable dynamics in the vegetation (Fuhlendorf and Engle 2004) produce similarly predictable changes in the small mammal community with increased dominance of $M$. ochrogaster, R. fluvescens, and S. hispidus and a decreased abundance of C. hispidus and P. maniculatus. Ultimately, the small mammal community in patches that have not been burned for several years within the Shifting Mosaic treatment become nearly indistinguishable from control patches. $M$. ochrogaster and $R$. fluvescens might increase with an additional year or two without fire and grazing, but that would result in lower densities of other species. From an evolutionary 
perspective, the pattern and return interval of fires would have been much more variable and potentially would provide patches that were not disturbed for longer periods.

\section{MANAGEMENT IMPLICATIONS}

Spatial and temporal patterns of variability contribute to landscape patchiness and have been suggested for an important focus for conservation (Christensen 1997; Wiens 1997; Fuhlendorf et al. 2006). Traditional conservation and management of grassland ecosystems has focused on minimizing severe disturbance and maximizing uniform disturbance. When preservation has been a focus, grazing often has been uniformly removed from grasslands and fire has been applied uniformly. Neither of these approaches is capable of producing a shifting mosaic landscape that was important during the evolutionary history of these grasslands. Both native flora and fauna respond to this pattern, supporting historical accounts and recent studies that suggest fire and grazing interacted on these landscapes resulting in a landscape that includes patches that have been intensively disturbed with fire and grazing, some that have been minimally disturbed for several years, and other patches with an intermediate time since disturbance.

Given the current fragmented status of the Great Plains grasslands, recovery or conservation of historical patterns of landscape variability and heterogeneity is highly unlikely, primarily because of the vast spatial scales at which these occurred. Analysis of multiple scales is necessary to accurately describe relationships between organisms and their environment (Fuhlendorf and Smeins 1996, 1999). Thus, caution should be used when interpreting the significance of traditional vs. shifting mosaic management techniques on species of small mammals without considering the spatial scale at which these processes are observed. However, re-creating a shifting mosaic of vegetation patterns dispersed across the landscape more closely resembles the evolutionary forces that shaped modern native grasslands as opposed to the more homogenous-based systems that are currently implemented throughout the Great Plains. Assuming historical disturbance patterns presumably provided variation in habitat types that maximized biodiversity, attempting to re-create the role of spatial and temporal variability at any scale may be a critical component in sustainable management of rangeland ecosystems. Further, if the scale of response is known for a given set of species, the scale of disturbance in the Shifting Mosaic could be altered to match so that the community stabilizes. Yet within this overall stable community and landscape, there would inherently exist great stochasticity as disturbances ebbed and flowed among patches, resulting in a landscape where all niches are met simultaneously.

\section{ACKNOWLEDGMENTS}

We thank J. Wier, T. Tunnell, C. Stansberry, and C. Cummings for contributions to the application of treatments and data collection. We also thank T. Bidwell for review of the manuscript. This article is published with the approval of the director at the Oklahoma Agricultural Experiment Station.

\section{LITERATURE CITED}

Anderson, R. H., S. D. Fuhlendorf, and D. M. Engle. 2006. Soil N availability in tallgrass prairie under the fire-grazing interaction. Rangeland Ecology and Management 59:625-631.

Balley, D. W., J. E. Gross, E. A. Laca, L. R. Rittenhouse, M. B. Coughenour, D. M. SWIFT, AND P. L. Sims. 1996. Mechanisms that result in large herbivore grazing distribution patterns. Journal of Range Management 49:386-400.

Bragg, T. B., And L. C. Hulbert. 1976. Woody plant invasion of unburned Kansas bluestem prairie. Journal of Range Management 29:19-24.

Briggs, J. M., A. K. Knapp, and B. L. Brock. 2002. Expansion of woody plants in tallgrass prairie: a 15 -year study of fire and fire-grazing interactions. American Midland Naturalist 147:287-294.

Briske, D. D., J. D. Derner, J. R. Brown, S. D. Fuhlendorf, W. R. Teague, K. M. Havstad, R. L. Gillen, A. J. Ash, And W. D. Wilms. 2008. Rotational grazing on rangelands: reconciliation of perception and experimental evidence [synthesis]. Rangeland Ecology and Management 61:3-17.

Briske, D. D., S. D. Fuhlendorf, and F. E. Smeins. 2003. Vegetation dynamics on rangelands: a critique of the current paradigms. Journal of Applied Ecology 40:601-614.

Christensen, N. L. 1997. Managing for heterogeneity and complexity on dynamic landscapes. In: S. A. Pickett, R. S. Ostfeld, M. Shachak, and G. E. Likens [EDS.]. The ecological basis for conservation: heterogeneity, ecosystems, and biodiversity. New York, NY, USA: Chapman and Hall. p. 167-186.

Clark, B. K., B. S. Clark, T. R. Homerding, and W. E. Munsterman. 1998. Communities of small mammals in six grass dominated habitats of southeastern Oklahoma. The American Midland Naturalist 139:262-268.

Coluins, S. L. 1992. Fire frequency and community heterogeneity in tallgrass prairie: a field experiment. Ecology 73:2001-2006.

Coluins, S. L., S. M. Glenn, And D. J. Gibson. 1995. Experimental analysis of intermediate disturbance and initial floristic composition: decoupling cause and effect. Ecology 76:486-492.

Coppedge, B. R., D. M. Engle, C. S. Toepfer, and J. M. Shaw. 1998a. Effects of seasonal fire, bison grazing and climatic variation on tallgrass prairie vegetation. Plant Ecology 139:235-246.

Coppedge, B. R., D. M. Leslie, and J. H. Shaw. 1998b. Botanical composition of bison diets on tallgrass prairie in Oklahoma. Journal of Range Management 51:379-382.

Coppedge, B. R., And J. H. Shaw. 1998. Bison grazing patterns on seasonally burned tallgrass prairie. Journal of Range Management 51:258-264.

Forman, R. T., ANd M. Godron. 1986. Landscape ecology. New York, NY, USA: John Wiley and Sons. 619 p.

Fox, B. J., AND M. D. Fox. 2000. Factors determining mammal species richness on habitat islands and isolates: habitat diversity, disturbance, species interactions and guild assembly rules. Global Ecology and Biogeography 9:19-37.

Fox, B. J., J. E. TAyloR, and P. T. Thompson. 2003. Experimental manipulation of habitat structure: a retrogression of the small mammal succession. Journal of Animal Ecology 72:927-940.

Funlendorf, S. D., ANd D. M. Engle. 2001. Restoring heterogeneity on rangelands: ecosystem management based on evolutionary grazing patterns. Bioscience 51:625-632.

Fuhlendorf, S. D., And D. M. Engle. 2004. Application of the fire-grazing interaction to restore a shifting mosaic on tallgrass prairie. Journal of Applied Ecology 41:604-614.

Fumlendorf, S. D., D. M. Engle, D. C. Arnold, and T. G. Bidwell. 2002. Influence of herbicide application on forb and arthropod communities of North American tallgrass prairies. Agriculture, Ecosystems, and Environment 92:251-259.

Funlendorf, S. D., D. M. Engle, J. Kerby, and R. Hamilton. 2009. Pyric herbivory: rewilding landscapes through the recoupling of fire and grazing. Conservation Biology 23:588-598.

Funlendorf, S. D., W. C. Harrell, D. M. Engle, R. G. Hamilton, C. A. Davis, and D. M. LESLIE, JR. 2006. Should heterogeneity be the basis for conservation? Grassland bird response to fire and grazing. Ecological Applications 16: 1706-1716. 
Fuhlendorf, S. D., And F. E. Smeins. 1996. Spatial scale influence on long-term temporal patterns of a semi-arid grass-land. Landscape Ecology 11:107113.

Funlendorf, S. D., and F. E. Smeins. 1997. Long-term vegetation dynamics mediated by herbivores, weather and fire in a Juniperus-Quercus savanna. Journal of Vegetation Science 8:819-828.

Funlendorf, S. D., and F. E. Smeins. 1998. Soil heterogeneity influence on plant species response to grazing within a semi-arid savanna. Plant Ecology 138:89-96.

Funlendorf, S. D., and F. E. Smeins. 1999. Scaling effects of grazing in a semi-arid savanna. Journal of Vegetation Science 10:731-738.

Fuhlendorf, S. D., F. E. Smeins, and C. A. Taylor. 1997. Influence of tree size and browse history on understory relationships of Ashe juniper. Journal of Range Management 50:507-512.

Grant, W. E., and E. C. Birney. 1979. Small mammal community structure in North American grasslands. Journal of Mammalogy 60:23-36.

Hobbs, R. J., D. S. Schimel, C. E. OwensBy, and D. S. OJima. 1991. Fire and grazing in the tallgrass prairie: contingent effects on nitrogen budgets. Ecology 72:1374-1382.

Kaufman, D. W., and E. D. Fleharty. 1974. Habitat selection by nine species of rodents in north-central Kansas. The Southwestern Naturalist 18:443-451.

Kaufman, D. W., S. K. Peterson, R. Fristik, and G. A. Kaufman. 1983. Effect of microhabitat features on habitat use by Peromyscus leucopus. The American Midland Naturalist 110:177-185.

Kaufman, G. A., D. W. Kaufman, and E. J. Finck. 1988. Influence of fire and topography on habitat selection by Peromyscus maniculatus and Reithrodontomys megalotis in ungrazed tallgrass prairie. Journal of Mammalogy 69:342-352.

KolASA, J., AND S. T. A. PICKETT. 1991. Ecological heterogeneity. New York, NY, USA: Springer-Verlag. $332 \mathrm{p}$
LudwiG, J. A., And D. J. Tongway. 1995. Spatial organisation of landscapes and its function in semi-arid woodlands, Australia. Landscape Ecology 10:51-63.

McMurry, S. T., R. L. Lochmiller, J. F. Boggs, D. M. Leslie, JR., and D. M. Engle, 1996. Demography and condition of populations of white-footed mice (Peromyscus leucopus) in late and early successional habitats. Journal of Mammalogy 77:335-345.

Ostfeld, R. S., S. T. Pickett, M. Shachak, and G. E. Likens. 1997. Defining scientific issues. In: S. T. Pickett, R. S. Ostfeld, M. Shachak, and G. E. Likens [EDS.]. The ecological basis for conservation: heterogeneity, ecosystems, and biodiversity. New York, NY, USA: Chapman and Hall. p. 3-10.

Patten, R. S., and J. E. Ellis. 1995. Patterns of species and community distributions related to environmental gradients in an arid tropical ecosystem. Vegetation 117:69-79.

Rose, R. K., and E. C. Birney. 1985. Community ecology. In: R. H. Tamarin [ed.] Biology of New World Microtus. Special Publication No. 8. Shippensburg, PA, USA: The American Society of Mammalogists. p. 310-339.

Teague, W. R., S. L. Dowhower, and J. A. Waggoner. 2004. Drought and grazing patch dynamics under different grazing management. Journal of Arid Environments 58:97-117.

Twidwell, D., S. D. Fuhlendorf, D. M. Engle, and C. A. Taylor. 2009. Surface fuel sampling strategies: linking fuel measurements and fire effects. Rangeland Ecology \& Management 62:223-229.

Wiens, J. A. 1976. Population responses to patchy environments. Annual Reviews of Ecology and Systematics 7:81-120.

WiENS, J. A. 1997. The emerging role of patchiness in conservation biology. In: S. T. Pickett, R. S. Ostfeld, M. Shachak, and G. E. Likens [EDs.]. The ecological basis for conservation: heterogeneity, ecosystems, and biodiversity. New York, NY, USA: Chapman and Hall. p. 93-107. 